\title{
Efficiency of Chemical Treatments on Reduction of COD and Turbidity of Deinked Pulp Waste Water
}

\author{
SHADEMAN POURMOUSA ${ }^{1}$ and SOMAYEH SOLTANI PARAFTABI ${ }^{2}$ \\ ${ }^{1}$ Department of Wood and Paper Science and Technology, Faculty of Agriculture and Natural \\ Resources, Karaj Branch, Islamic Azad University. Karaj, Iran. \\ ${ }^{2}$ Department of Environment Science, Science and Reseaech Branch, \\ Islamic Azad University, Sistan and Baluchistan, Zahedan, Iran.
}

http://dx.doi.org/10.12944/CWE.8.3.09

(Received: August 07, 2013; Accepted: November 05, 2013)

\begin{abstract}
The effect of poly aluminum chloride with cationic or anionic polymers in treatment of deinked waste water has been studied. The experiments were carried out in jar tests with poly aluminum chloride dosages range of $5-20 \mathrm{mg} / \mathrm{l}$, cationic or anionic polymers dosages range of 1 $3 \mathrm{mg} / \mathrm{l}, \mathrm{pH}$ range of $7.2-8.2$, rapid mixing at $100 \mathrm{rpm}$ for 2 minute, followed by slow mixing at $40 \mathrm{rpm}$ for 10 minute and settling for 20 minute. The effectiveness of poly aluminum chloride with cationic or anionic polymers were measured based on reduction of turbidity and chemical oxygen demand. The combination of poly aluminum chloride with cationic or anionic polymers is found to give the increase efficiency of purification in the treatment of the deinked waste waters. it can achieve almost66.82 \% of turbidity and $63.04 \%$ ofchemical oxygen demand reduction at an optimum dosage of $15 \mathrm{mg} / \mathrm{l}$ poly aluminum chloride with $3 \mathrm{mg} / \mathrm{l}$ cationic polymers andpH of 8.2. Theresult suggests that the waste water purified can be used for internal process applications but for injection it to environments goals can be passed biological treatments.
\end{abstract}

Key words: Deinked waste water, Chemical treatments, Turbidity, Chemical Oxygen Demand, Efficiency.

\section{INTRODUCTION}

The pulp and paper industry is one of the oldest industrial sectors in the world. It is a highly capital, energy and water intensive industry with highly polluting process and requires sustainable investments in pollution control methods and equipment.

In the pulp and paper industry, a huge amount of water flowsthrough different processes. For environmental and economic reasons, the plant recycles the water as much as possible. Before recycling the water is purified to a certain degree. The chemical treatment is one of purification methods. The dosing control of chemicals is very demanding because the quality of water may fluctuate considerably and the effects of chemicals on the purification stage 1 .
The pulp and paper waste water contains a large amount of pollutants characterized by Biochemical Oxygen Demand (BOD), Chemical Oxygen Demand (COD), suspended solids (SS), toxicity and colorants which cause bacterial and algal slime growth, thermal impacts, scum formation, color problems and a loss of both biodiversity and aesthetic beauty in the environment ${ }^{2}$.

Several researches have been studied on biological, chemical and physicochemical treatment of pulp and paper mills waste water 3,4 .based on Thompson et al, the pulp and paper mills waste water have low BOD/COD ratio usually between0.02-0.07. Morais et al believed that the low ratio of $\mathrm{BOD} / \mathrm{COD}$ makes the biological treatment methods inappropriate for pulp and paper mills waste water ${ }^{5}$. 
Waste water treatment of pulp and paper mills consumed the large amount of chemicals using alum, ferric chloride, ferric sulphate and lime through chemical processes6. So it seems that physic- chemical processes should be interesting method for treatment of the pulp and paper mills waste water because of they are economic and based on the coagulation - flocculation process of small particles followed by an adjusted settling time ${ }^{7}$.

Deinked pulp waste wateris one of the pulp and paper conventional effluents that have especially distinctions. The recycling rate of waste papers has steadily increased decades as parts of the effort to preserve forest resources and reduce the cost of municipal waste treatment. In this work, the effect of chemicals (poly aluminum chloride with cationic or anionic polymers) investigated on deinked pulp and paper mill waste water in order to reduction of COD and turbidity and the measurement of maximum efficiency purification.

\section{MATERIALS AND METHODS}

The waste water was collected from the waste water treatment plant of tissue producing mill of white mixed waste papersat Iran. The samples were taken at overflow of physical treatment stage of plant facility. Waste water samples were characterized and the analyses in Table 1. The parameters were measured based on Standard
Methods for the Examination of water and waste water (APHA 1998).

All chemicals used analytically pure chemicals is commercial grade products. Anionic flocculants provided with the commercial cod of GFLOC A190 from Aquatech Company. Cationic flocculants obtained with the commercial cod of NUFLOC F10 from GIG Company. Poly aluminum chloride(PAC) provided from Iranian chemistry Company. Deion water was used to make all solutions.The chemicals were diluted to a concentration of 0.1 Percentages. Then the diluted solution was added to waste water samples. Table 2 shows the important properties of the chemicals that used in research.

Coagulation and flocculation tests were conducted using a conventional jar test apparatus. In each run, one liter samples were poured into six jars. Different dosages of chemicals(at first polyaluminum chloride and then cationic or anionic polymers ) were then added and the coagulation began with rapid mixing of 100 RPM for $2 \mathrm{~min}$, followed by slow stirring of 40 RPM for $10 \mathrm{~min}$. the flocks formed were then allowed to settlefor $20 \mathrm{~min}$. The end of sedimentation was set at a time when no appreciable flock settlement was observed. Finally, supernatant was withdrawn with a plastic syringe from near $2 \mathrm{~cm}$ below the liquid- air interface for chemical analysis. All the experiments were

Table1: Waste water samples were characterized and the analysed

\begin{tabular}{lcccccc}
\hline Distinction & pH & COD & Turbidity & TSS & TDS & Conductivity \\
\hline Unit & & $\mathrm{mg} / \mathrm{l}$ & $\mathrm{FTU}$ & $\mathrm{mg} / \mathrm{l}$ & $\mathrm{mg} / \mathrm{l}$ & $\mathrm{ms} / \mathrm{cm}$ \\
Equalization tank & 7.02 & $>5000$ & $>1000$ & 4500 & 4100 & 3.40 \\
Overflow of physical & 7.07 & 3562.33 & 117.23 & 1546 & 2670 & 3.07 \\
Treatment & & & & & & \\
\hline
\end{tabular}

Table 2: The important properties of the chemicals used in research

\begin{tabular}{|c|c|c|c|c|c|c|}
\hline Chemicals & $\begin{array}{l}\text { Commercial } \\
\text { name }\end{array}$ & Company & $\begin{array}{l}\mathrm{pH} \\
1 \mathrm{mgr} / \mathrm{l}\end{array}$ & $\begin{array}{l}\text { Cond } \\
\mu \mathrm{s} / \mathrm{cm}\end{array}$ & $\begin{array}{l}\text { TDS } \\
\mathrm{mg} / \mathrm{l}\end{array}$ & $\begin{array}{l}\text { Abbreviation } \\
\text { at research }\end{array}$ \\
\hline $\begin{array}{l}\text { Poly aluminum } \\
\text { chloride }\end{array}$ & PAC & $\begin{array}{l}\text { Iranian } \\
\text { chemistry.CO }\end{array}$ & 4 & 75.5 & 3710 & $\mathrm{Pac}$ \\
\hline Cationic polymer & NUFLOC F10 & GIG & 5.7 & 121.5 & 60.8 & cat \\
\hline Anionic polymer & GFLOC A190 & Aquatech & 8 & 222 & 153.4 & ani \\
\hline
\end{tabular}




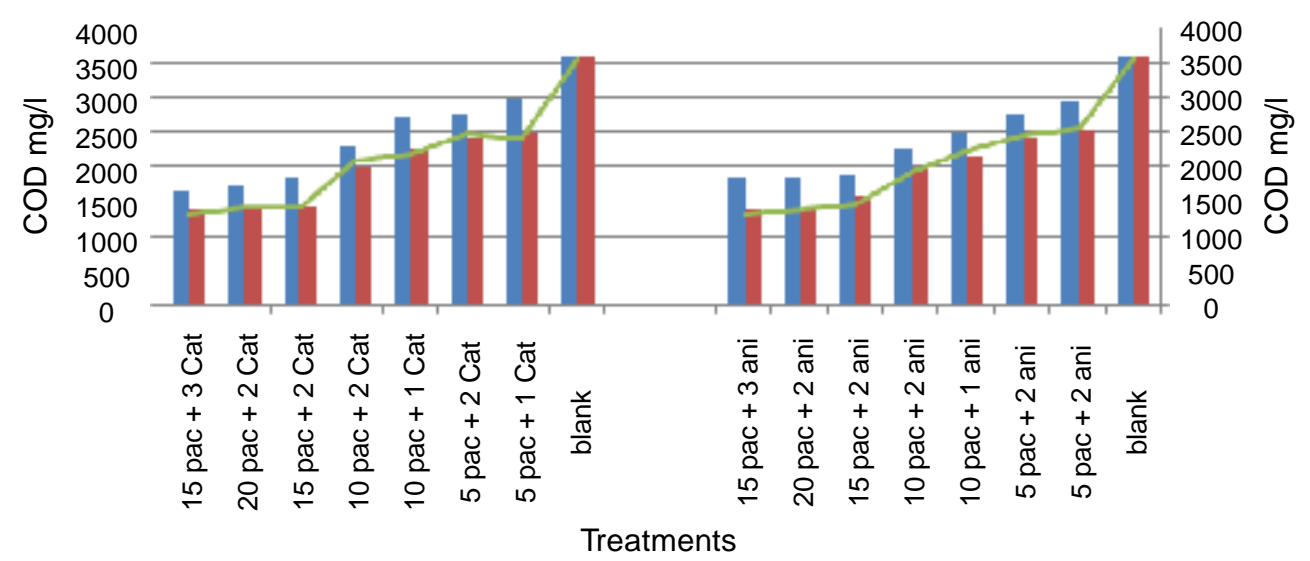

Fig. 1: Effect of chemical treatment on COD reduction at different $\mathrm{pH}$

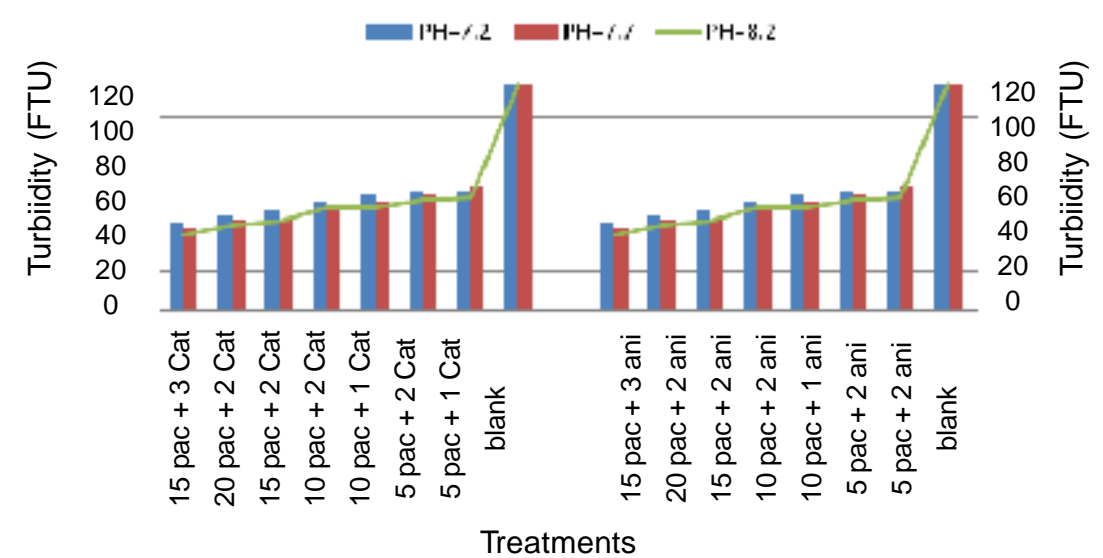

Fig. 2: Effect of chemical treatment on Turbidity improvement at different pH

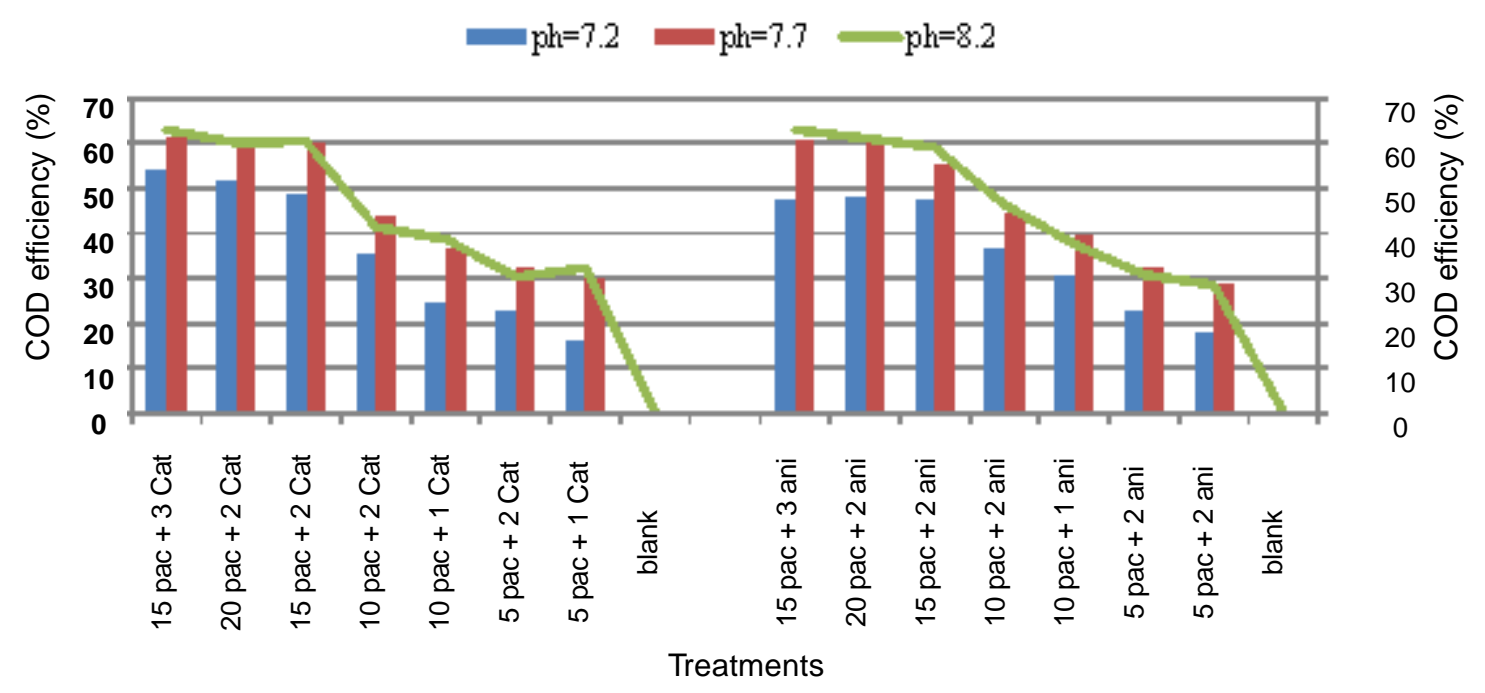

Fig. 3: Comparison of COD Efficiency at the different pH 
carried out at ambient temperature of $23-25$ $0 c$.Decrease or increase of $\mathrm{pH}$ from control position to designed plan by adding of $\mathrm{H}_{2} \mathrm{SO}_{4}$ and $\mathrm{NaOH}$ was done.

Turbidity was measured by a turbid meter manufactured by Eutech (Model 2100A). Turbidity was measured by putting $10 \mathrm{~mL}$ of sample into turbidity cell and places it in turbidity meter to measure turbidity.Chemical Oxygen Demand was determined by the potassium dichromate method.

Waste water samples were treated by different dosages of poly Aluminum Chloride and
Cationic or Anionic polymers at three replications. The average ofdataobtained with SPSS software ${ }^{16}$.efficency of each treatment calculated via differences of inlet and outlet to inlet of each treatment.

\section{RESULTS AND DISCUSSION}

Waste water distinctions at equalization tank and Overflow of physical Treatment summarized in Table 1. Table 2 shows the important properties of the chemicals that used in the research.Comparison of results were made for treatments based on turbidity and chemical oxygen

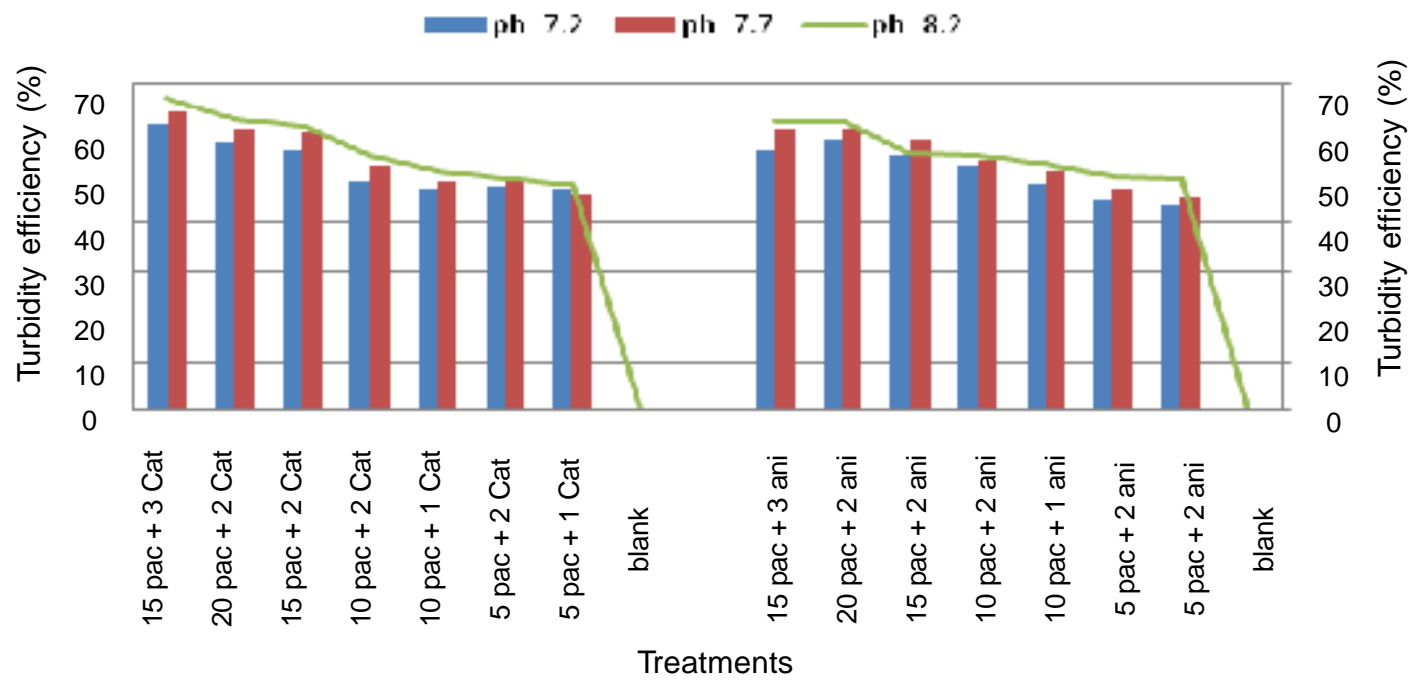

Fig. 4: Comparison of Turbidity Efficiency at the different pH

-Turbidity $\square \mathrm{COD}$

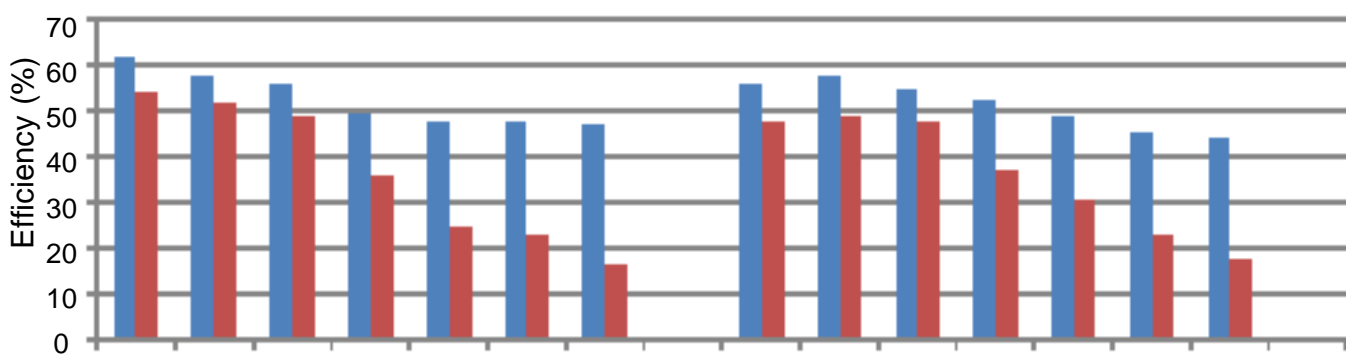

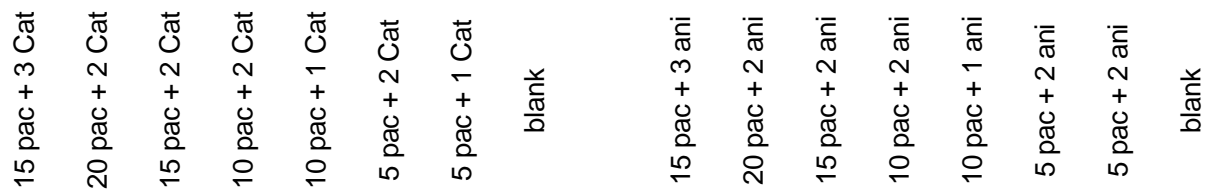

Treatments

Fig. 5: Comparison of COD and Turbidity Efficiency at the $\mathrm{pH}=7.2$ 
demand at variation of $\mathrm{pH}$ conditions are shown in Fig of 1 to 7 .

In order to design the best treatment for removal of COD and turbidity improvement, the research continued at three range of $\mathrm{pH}$.The impact of different dosages of poly aluminum chloride with cationic or anionic polymers at three range of waste water $\mathrm{pH}$, on chemical oxygen demand reduction, turbidity improvement and performance efficiency are shown at Fig 1 to 7 .

Based on figures, the impact of chemicals was utilized on quality of waste water clarification. the best results for COD reduction, take place at injection of $15 \mathrm{mg} / \mathrm{l}$ poly aluminum chloride with 3 $\mathrm{mg} / \mathrm{l}$ cationic or anionic polymerstowaste water at $\mathrm{PH}$ : 8.2.at this position the performance efficiency of each treatment for COD reduction from $3562.33 \mathrm{mg} / \mathrm{l}$ at blank samplesreached to1316.67$1317.83 \mathrm{mg} / \mathrm{l}$ where is equal to $63.02-$ $62.01 \%$ performance efficiency of COD removal respectively (Fig 1\&3).COD removal at $\mathrm{pH}: 7.2$ take place with low efficiency at treatments. But the performance of COD removal increased at $\mathrm{pH}$ : 7.7and 8.2. Atthis range of $\mathrm{pH}$,have not differences significantlyexcept at first treatments.

T urbidity $\square \mathrm{COD}$

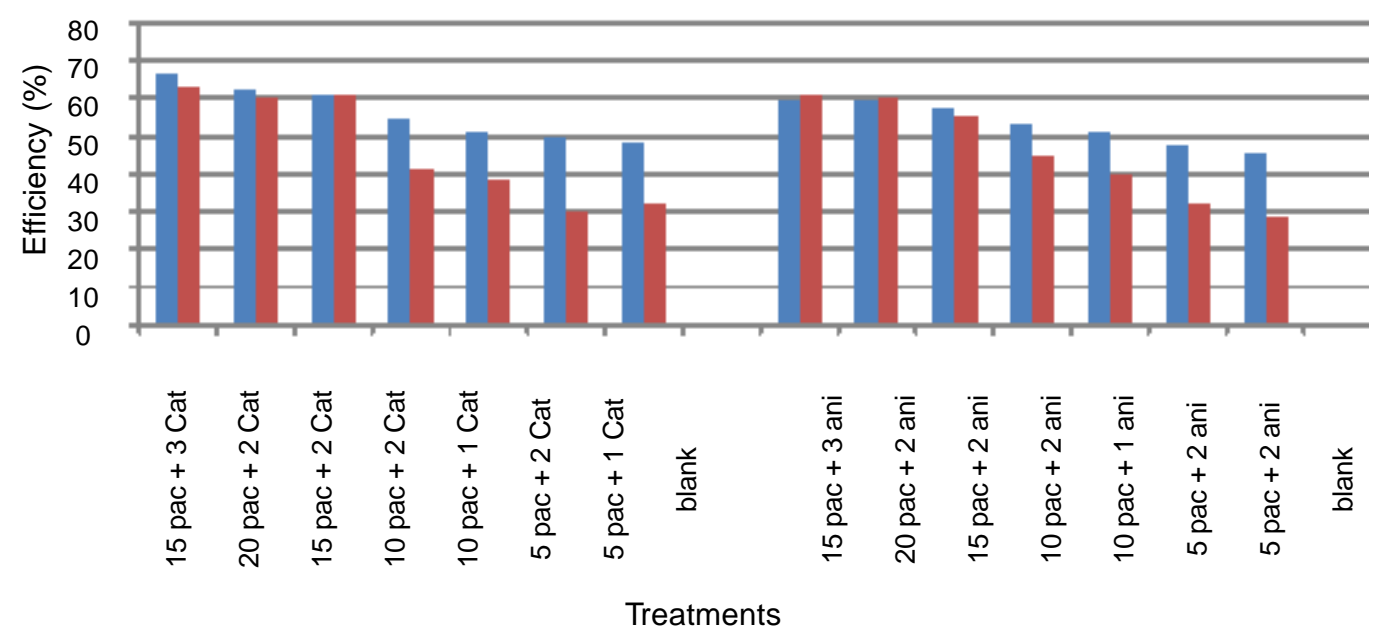

Fig. 6: Comparison of COD and Turbidity Efficiency at the pH=7.7

- Turbidity $\square \mathrm{COD}$

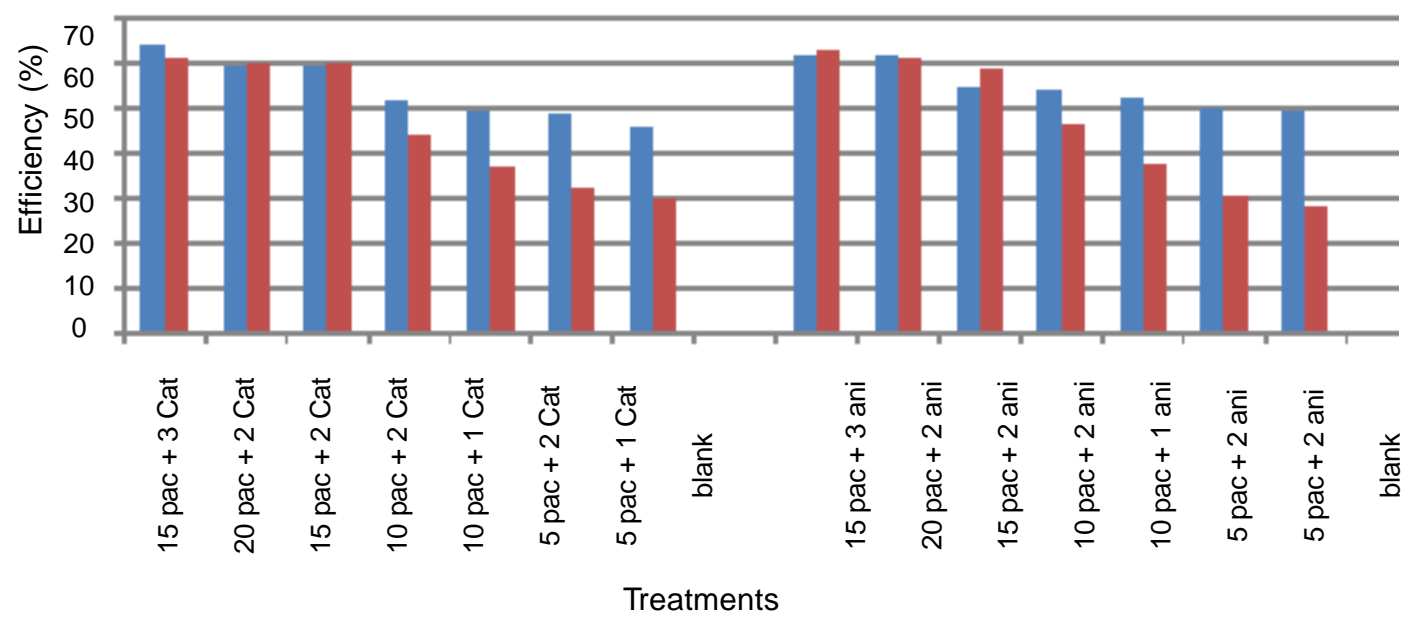

Fig. 7: Comparison of COD and Turbidity Efficiency at the $\mathrm{pH}=8.2$ 
According to the figures, the best treatments for turbidity improvement take place attreatment of $15 \mathrm{mg} / \mathrm{l}$ poly aluminum chloride with $3 \mathrm{mg} / \mathrm{l}$ cationic polymers to waste water at $\mathrm{pH}: 8.2$.at this position the performance efficiency of the treatment for turbidity improvement reached from 117.23FTU reached to $38.9 \mathrm{FTU}$ that is equal $66.82 \%$ turbidity improvement efficiency (figures 2 \& 4).Turbidity improvement at $\mathrm{pH}: 8.2$ take place with high efficiency at treatments compared to other $\mathrm{pH}$.

The trend of variations at the treatments showed, the behavior of polymers is very sophisticated at different levels of poly aluminum chloride injection. So cannot tell which kind of polymers is better than other.it seemed the application of each polymers depended to anionic and cationic traces at deinked pulp waste water effluent. The efficiency of performance at high levels of chemical consumption and upper $\mathrm{pH}$ goes better than low levels. The turbidity improvement efficiency was better than COD Reduction performance at all conditions (Fig 5-7).

\section{CONCLUSION}

Reduction of COD and turbidity has been studied using different dosages of poly aluminum chloride with cationic or anionic polymers at three range of $\mathrm{pH}$. The results showed that the combination of poly aluminum chloride and polymers is more effective at coagulation and flocculation process.it can achieve $63.04 \%$ of COD and $66.82 \%$ of turbidity reduction at the optimum dosages of $15 \mathrm{mg} / \mathrm{l}$ of polyaluminum chloride with $3 \mathrm{mg} / \mathrm{l}$ cationic polymers. The waste water at this purification quality level can be used for internal process goals but without biological treatments it can't be inject to environment and outdoors applications.

\section{REFERENCES}

1. Esko, k.juuso.,Dynamic simulation of water treatment in pulp and paper industry, control engineering laboratory, depts. Of process engineering, 90014, University of Oulu, Finland (2009).

2. Pokhrel, D. and Viraraghavan.T., Total Environment., 333:37-58 (2004).

3. Rintala, J., Martin,J.L.S., and Lettinga,G., Water Sci: Technol., 24:149-160 (1991).

4. Rintala, J., and Puhakka,J.A.P.,A review.Bioresour.Thechnol., 47: 148 (1994).
5. Thompson,G., J.Swain,M.Kay and Forster.C.F., Bioresour. Technol.,77: 275-286 (2001).

6. Stephenson,R.J., and Duff,S.J.B., Water Res. 30: 781-792 (1996).

7. Kadhum M. shabeeb, Haydar A. Abdulbari, Ali A. Abbas., Al-Qadisiya J.for Eng. Sci, 4, NO:4 (2011).

8. APHA, Standard Methods for the Examination of Water and Waste Water 20 th Edn.,American Public Health Association, Washengton, DC (1998). 